\title{
The Achievement of National Education Standard of Private Senior High School of Rural Area
}

\author{
Dadi Setiadi* \\ Department of Educational \\ Administration \\ University of Mataram \\ Mataram, Indonesia \\ setiadi_dadi@unram.ac.id
}

\author{
Hamid Syukrie ZM \\ Department of Educational \\ Administration \\ University of Mataram \\ Mataram, Indonesia \\ hamidsyukriezm@unram.ac.id
}

\author{
F Fahruddin \\ Department of Educational \\ Administration \\ University of Mataram \\ Mataram, Indonesia \\ Fahruddin.fkip@unram.ac.id
}

\begin{abstract}
This electronic document is a "live" template and already defines the components of your paper [title, text, heads, etc.] in its style sheet. *CRITICAL: Do Not Use Symbols, Special Characters, Footnotes, or Math in Paper Title or Abstract. (Abstract) The quality of educational units between state senior high school and private school are high different especially in schools in the rural area. However, the private school of rural areas, that the accomplishment of the national educational standard is a very hard effort meanwhile supporting from educational office including public is very low. This study aims to deeply analyze the achievement of the national education standard of Private Senior High School as basic data for designing a program of student's quality improvement. This study uses a qualitative approach of a sort case study. The data and resources used are primary and secondary. Moreover, data are collected by interview, documents, observation, and analyzed with exploring the general meaning of data, interpretation of findings, and validation of finding. The results show that the standard of management, financial, teacher and educational staff, facilities, process, and evaluation have not fulfilled the national standard even though the score is good. The management of headmasters does not use modern leadership including financial management. The number of the teachers of the school are from several other schools who fulfill the duty of teaching regarding getting certification. Moreover, the facilities have not completed standards including process and evaluation due to others not accomplishing well. The school needs a big effort from the basics to achieve all very good education standards and should be guided by educational office staff and society including support in regarding to improve students' quality.
\end{abstract}

\section{Keywords—education standard, private senior high school.}

\section{INTRODUCTION}

This study is about the achievement of national educational standard as a basic program improvement of private school caused by the students' school quality is lower than others in city areas such as national school exam. National Education Standards are the minimum criteria regarding the Republic of Indonesia's education system in all jurisdictions [1]. National Education Standards are standards that must be met by educational units consisting of the standard of Graduate Competency, Content, Process, Teachers and Education staff, Facilities and Infrastructure, Management, Financing, and Evaluations.

The National Education Standards function as the basis for planning, implementing, and supervising education to realize the goals of quality national education. The National
Education Standards aim to ensure the quality of national education in the context of the nation's intellectual life and shape the character and civilization of the nation with dignity. National Education Standards are based on standards that are interrelated from one standard to another which will always be improved in a planned, directed, and sustainable manner following the changing demands of local, national, and global life. In addition, the equalization of standardization can be done through the intention of guidance from the government and also those who care about the progress of Indonesian education. The involvement of experts in the field of education administration and management can be one solution that can be taken for the advancement of management education [2].

Based on the national education standards, to measure the level of achievement following using the indicators of each standard, to achieve a good graduate competence standard requires support from every other educational standard. In addition, the obstacles encountered in fulfilling standards at the education unit level are especially the Educator and Education Personnel Standards, the Standard for Facilities and Infrastructure, and the Standard for Financing [3]. Thus schools must always direct their school programs to refer to the achievement of national education standards for the fulfillment of the eight National Education Standards (SNP) which can affect the improvement of the quality of school education delivery and contribute to the success of accreditation [4]. However, several schools are getting A and B score, but among these schools, there are still quite a few which have low school quality [5].

Private Senior High Schools in rural locations have their problems related to meeting all national standards, including their graduates' quality. The condition is a problem in improving the school quality, so need to know about the basic problem faced by the school as preliminary data for helping the institution This is because these schools have limited fulfillment but need to be respected for their enthusiasm in carrying out their duties, especially teacher and educational staffs in educating their students. The purpose of this study was to determine the level of fulfillment of national education standards and how to improve the quality of students.

\section{METHODS}

The Qualitative method with a case study was used in this research. The study was carried out in private senior high schools in Narmada Sub District. The study subject was teachers, headmasters, and superintendent of schools. Data 
were collected by analyzing documents of the school development plan, and lesson plan, and interviewing school teachers, headmasters, and questionnaires were given to school teachers, headmasters and superintendent. Data analyzed technique used in this qualitative study namely data collected, data analyses preparation, read all data, data code, text and theme code for the study report.

\section{RESULTS AND DISCUSSION}

Fulfillment of Graduate Competency standards, based on the elements of graduate competency standards, has not been maximally fulfilled in the aspect of attitudes, knowledge, and skills, it still needs to be improved to achieve the competency standards of graduates. Apart from the graduates produced, it is still very rare to qualify for good public universities. In addition, according to [19], four standards are still very low in achievement, namely standards of facilities and infrastructure, process standards, competency standards of graduates, and standards of educators and educational personnel. In connection with this, it is still very much needed effort and hard work from the school as a whole to be able to carry out the process of learning, guidance, deepening and training to meet the national standard.

Content Standards, seen from the fulfillment of content standards, have not met the national education standard which includes the basic framework and curriculum structure, learning load, education unit level curriculum, but in the aspect of learning load, it becomes a separate problem including aspects of the evaluation of demanding learning processes and outcomes. Learners have to get higher mastery of the material content and require more time needed. To save more time at school, additional independent study at home is done.

The appropriate process standard has not fulfilled what is charged from the learning process standard, as well as seen from the planning in the form of a learning plan assessed from the quality of the content is not good where it is reflected that the lesson plan has not fulfilled the standard for the learning process based on active students where the teacher is only a facilitator. However the democratization in learning occurs openly and all students are allowed to dare to ask questions, express opinions, and argue [20]. Besides that, it is also necessary to develop student activity sheets that are more challenging for students to become independent learners and Methods, strategies and approaches cannot be separated from the three domains of cognitive, affective and psychomotor and all transformed knowledge has been attempted to be embodied in shaping the character or attitude of students [21].

Teachers and education staff standards, when viewed from the fulfillment of professional certificates, not all personnel have professional certificates, namely the lack of teaching staff and education to attend training or seminar participants to increase professionalism as educators and educational staff such as routinely participate in activities through the Subject Teacher Conference (MGMP) [22] and seminars, or training following improving the quality of education [23]. The school has been doing to improve staff standard gradually in next years.

The standard of school facilities and infrastructure, aspects of educational facilities and infrastructure still need much attention from the government and the community as users both in terms of the number and quality of facilities. There is also a need for repairs due to natural disasters that require procurement and repair from the school, local government and the community in preparing facilities and infrastructure following educational standards.

Document management standards have been met, but the implementation has not been effective due to a lack of staff discipline in carrying out their job and control and supervision have not been properly implemented. So that the role of the head of the school must be emphasized even more in this school management,

Financing Standards, the funds managed by schools are very minimal when compared with the standards required. This condition greatly affects the quality of the overall quality. The source of funds from the government is very minimal because it is based on the number of students, besides that support from the parents of students cannot be expected because the average income is very limited including community participation in general. Thus schools must manage the very limited funds for the operational activities of the school and must be able to determine which priority scale is the main and which can support especially for the learning process.

Educational assessment standards, the assessment has not run according to the standard assessment criteria determined, especially the assessment of learning outcomes in the aspect of knowledge, attitudes and skills, so that the assessment carried out still needs to improve the skills of teachers in designing assessment instruments that meet the standard according to educational standards for secondary education.

Standard content is the scope of the material and the level of competence as outlined in the criteria for graduation competence, especially in study materials, subject competence, and learning syllabus that must be fulfilled by students at certain levels and types of education [1]. The results show that the competency level on documents related to content standards still needs to be improved from the aspect of depth and broad of the material based on the competencies of knowledge and skills, so that the content can be fulfilled.

Process standards are national education standards related to the implementation of learning in one education unit to achieve graduate competency standards [1]. Based on documents and observations, it shows that the process is not following the bill from the process that must be carried out according to the standard process bill. Some things need to be underlined. First, the national education standard, which means that this standard applies to every formal education institution at a certain level of education wherever that education is located nationally. Each education unit must plan the learning process, implement the learning process, assess learning outcomes, and supervise the learning process to implement an effective and efficient learning process [6].

Competency Standards for Graduates, the school has not shown achievement following the predetermined standards so it is necessary to conduct analysis related to the source of the cause while graduate content standard is the main source or reference in determining educational process standards [1]. Intended for secondary education in determining student graduation and assessment guidelines. Graduate competency 
standards are used as assessment guidelines in determining the graduation of students from educational units.

Teacher and Education Staff Standards, this means that "teachers and principals are professional actors who must apply their competence as educators maximally by fulfilling several conditions, to create output expected by institutions educational [1]. To maximize the potential for schools to be utilized in their management, schools should have administrative staff who are capable and understand the school administration system, so that teachers and education staff in schools do not lose data on school inventories. "The opinion about the achievement of teachers and education staff standards illustrates that in general, it is expected that schools have teachers and education staff who have standards following the Board of National Education Standard and can apply their competencies to the maximum. The teacher is central to efforts to improve the quality of education, therefore every effort to fix education will and must maintain the arrangement of teachers [7] and Teacher performance is an inseparable part of a system starting from input, process, and output, to achieve the goals of an educational institution [24].

In addition, teachers should have the competencies they already have and have multi-literacy skills, values nationalism, and perspective global [8]. According to [7] the leader of the education unit has the responsibility to create an organizational culture and a conducive climate for efforts to increase growth and enhance the development of educational institutions following the required quality standards. In addition, the contribution of school supervisors can improve quality in the aspect of academic supervision in the form of guidance on content standards, process standards, graduate competency standards, and educational assessment standards given to teachers. [9]. teachers who are at the forefront of learning in the field / school need to formulate a learning model as an implementation of the education unit level curriculum [10]. Also, the placement of educators according to their respective expertise as teaching staff increases the quality of teaching staff and educational personnel [6]. Another thing that needs to be considered is the principle of service for teachers and education staff, namely the inform of cooperation efforts in educational organizations to achieve goals in the form of planning, selection, coaching activities, to the end of teachers and education staff for effective and efficient results [11].

Process standard learning should be interactive, inspiring, fun, challenging, motivating students to participate actively and provide sufficient space for initiative, creativity, and independence according to students' talents, interests, and physical and psychological development [1]. This is related to how the process is carried out by teachers to be given experience learning that fits the need. In addition, the contribution of eight national education standards to the learning process was $22.5 \%$. This means that $77.5 \%$ of the success of the learning process is determined by other factors, both internal and external, such as motivation, interests, parental background, school environment [12]. In core activities, it should use learning models, methods, media, and resources that are tailored to the characteristics of students and subjects [13].

The standard for Facilities and Infrastructure shows that they do not meet the overall standard of infrastructure, while facilities are very important to carry out the learning process and this will have an impact on learning outcomes. Standard facilities and infrastructure are managed by the management of private schools in which schools can ask for assistance to the government through grants and can also be obtained from the foundation [14]. Nevertheless, management performed against the standard school-owned facilities and infrastructure should be adjusted to national standards [1]. Related to the contribution of supervisors, it can be in the form of guidance regarding standards of educators and education personnel, standards of facilities and infrastructure, management standards, the standard of financing provided to school principals, deputy school principals, and heads of administration [9].

Management standards in private schools already have appropriate national education standards and can provide information about school management [1]. Management led by the principal has not met management standards due to several factors where it begins with the appointment that does not fulfill the competence as school principal due to intervention from the owner of the foundation so that the competence is not sufficient, especially in the implementation of school management. In addition, the success of the selfevaluation process is a prerequisite for the success of educational work planning, and the better the implementation of school self-evaluation and educational work planning, the clearer the efforts to improve the quality of education in a school [15]. Also, if school leaders carry out planning, socialization, implementation and evaluation as well as a follow-up that is not carried out with good management to meet national education standards, it will hamper the implementation and improvement of the quality of school education. [16]

Funding standards in private school management have an orientation to provide distribution of financing according to their respective priorities in several financing items. The implementation of work programs by school principals and treasurers is less transparent and less responsible, and there is even the possibility of deviant things being done in payment, honoraria, activities and spending of goods. In managing education financing, a mature planning concept and system is needed, to be able to formulate a system of national education standard financing [17].

Assessment Standards, which private schools carry out have not been carried out in a conducive manner and have planned steps starting from preparation, implementation, and follow-up [1]. This is indicated by the plan and implementation of the assessment in the learning plan document that has not fulfilled the bill from the curriculum document [18]. Preparation to meet the standards is done by forming a team, arranging a grid, and arranging the questions neatly and clearly. There is no difference in the achievement of the assessment standards applied in private schools and is still based on the BSNP (Badan Standar Nasional Pendidikan) as national education standard agency, however, the followup of the results of the assessments carried out at private schools encourages students to only be able to complete the predetermined minimum completeness criteria.

In the context of improving the quality of students in private schools in addition to meeting national education standards, there are still several factors that affect the quality 
of student learning outcomes as a whole. The National education standard is both a measure of the quality of schools that support each other. Quality assurance is sought to be fulfilled, especially by local governments, to be further improved to meet or higher than national education standard [25].

In general, the characteristics of students in these schools differ from the aspects of motivation, capacity, environmental and parental support. Therefore, educators must approach personal nature following the conditions of each student so that assistance could be given guidance under the conditions of each student so that they can make better achievements including characters.

\section{CONCLUSION}

The school has not achieved very well all national educational standards: graduate, content, process, teacher and educational staff, evaluation, management, financial and facilities. Due to limited financial income for the salary of staff, provide facilities especially for teaching. This study has produced a recommendation for the educational office to give more attention in helping the school to achieve national standards very well especially in improving students' quality in knowledge, skills and attitude due to private school students having unique character learning motivation and their support from their family and environment in general.

\section{ACKNOWLEDGMENT}

Thanks to the Rector of the University of Mataram for financial supporting and school headmaster and teachers for supporting this study.

\section{REFERENCES}

[1] Badan Standar Nasional Pendidikan https://bsnpindonesia.org/standar-nasional-pendidikan/

[2] M. F. Haq, "Analisis Standar Pengelolaan Pendidikan Dasar dan Menengah”, Evaluasi, vol. , no. 1, 2015

[3] L. Yuliana, dan S. B. Raharjo, "Ketercapaian Standar Nasional Pendidikan di Sekolah Menengah Atas", Jurnal Pendidikan dan Kebudayaan, vol 4, no. 2, 2019.

[4] F. Hanun, 2015. Keberhasilan Dalam Pemenuhan Standar Nasiona Pendidikan (SNP). EDUKASI: Jurnal Penelitian Pendidikan Agama dan Keagamaan (25)15

[5] S. B. Raharjo, L. Yuliana, Y. H. Yudha, "Capaian Standar Nasional Pendidikan Sebagai Prediktor Mutu Sekolah". Jurnal Pendidikan dan Kebudayaan, vol. 3, no. 2, 2018.

[6] A. S. F. Jaya, dan Ellyawati. "Implementasi Standar Nasional Pendidikan di Kabupaten Aceh Besar Suatu Persepsi dan Harapan Masyaraka”, Jurnal Dedikasi Pendidikan, vol. 3, no. 1, 2019.
[7] Hidayati, "Manajemen Pendidikan, Standar Pendidik, Tenaga Kependidikan, dan Mutu Pendidikan”, Jurnal Al-Ta'lim, vol. 21, no. 1, pp. 42-53, 2014.

[8] I. Lisnawati, "The Professionalism of Indonesian Teachers in The Future", Journal of Education, Teaching and Learning, vol. 3, no 1, pp. 28-33, 2018

[9] M. A. Sasmito, "Kontribusi Pengawas Sekolah Terhadap Pemenuhan Standar Nasional Pendidikan”, Journal of EST, vol. 1, no. 2, pp. 30-45. 2015.

[10] M. Sholeh, "Kajian Kritis Tentang Standar Nasional Pendidikan (SNP)", A 1-Tanzim, vol. 1, no. 1, pp. 36-55, 2017.

[11] T. Triwiyanto, "Standar Nasional Pendidikan Sebagai Indikator Mutu Layanan Manajemen Sekolah Jurnal Ilmu Pendidikan, vol. 19, no. 2, 161-171, 2013.

[12] S. B. Raharjo, "Kontribusi Delapan Standar Nasional Pendidikan Terhadap Pencapaian Prestasi Belaar",. Jurnal Pendidikan dan Kebudayaan, vol. 20, no 4, 2014.

[13] U. Mukarramah, A. Juanda, E. Fitriah, “Analisis Standar Proses Pembelajaran Biologi Kelas X di SMA Negeri 1 Majalengka Tahun Pelajaran 2014/ 2015”, Scientiae Educatia vol. 5, no 1, 2015.

[14] Nasyirwan, "Pencapaian 8 (Delapan) Standar Nasional Pendidikan Oleh Kepala Sekolah Untuk Meningkatkan Mutu Lulusan”, Manajer Pendidikan, vol. 9, no. 6, pp. 724-736, 2015.

[15] A. S. Chamidi, "Evaluasi Diri dan Perencanaan Kerja Pendidikan Bagi Peningkatan Mutu Sekolah/Madrasah", Journal Ar'rihlah: Inovasi Pengembangan Pendidikan Islam. Vo. 3, no 1, 2018.

[16] L. E. Cahyono, S. Budiwibowo, dan J. Murwani, "Analisis Penerapan 8 Standar Nasional Pendidikan Pada SMP Negeri 2 Dolopo Kabupaten Madiun”. Jurnal Akuntansi dan Pendidikan, vol. 4, no 2, 2015.

[17] K. R. Fironika, "Pembiayaan Pendidikan di Indonesia”, Jurnal Ilmiah Pendidikan Dasar. vol. 2, no 1, pp. 43-64, 2015.

[18] S. Wilian, D. Setiadi, Nyoman Sridana, "Analysis of the Implementation of Internal Quality Assurance System in Private Islamic High Schools in Mataram-Lombok", Advances in Social Science, Education and Humanities Research, volume 438. 4th Asian Education Symposium (AES), 2019.

[19] F. Alawiyah, "Standar Nasional Pendidikan Dasar dan Menengah National (Standards of Primary and Secondary Education)", Aspirasi, vol. 8, no. 1, 2017.

[20] A. S. Anwar, " Peningkatan Mutu Pendidikan Pada Madrasah Aliyah Model MAN 2 Kota Serang Provinsi Banten”, Al Tanzhim Jurnal Penelitian Manajemen Pendidikan, vol.1, no1, 2016.

[21] M. I. Abdi, dan S. Muri'ah, 2017. Implementasi Standar Nasional Pendidikan Pada Sekolah-Sekolah Unggulan di Samarinda. Fenomena, vol. 9,no 1, 2017.

[22] M. Sholeh, "Kajian Kritis Tentang Standar Nasional Pendidikan (SNP)", Al-Tanzim, vol. 1, no 1, 2017.

[23] H. Anwar, "Standar Pengelolaan Pendidikan Dalam Perspektif Pengelolaan Madrasah Aliyah Swasta". TADBIR: Jurnal Manajemen Pendidikan Islam, vol. 5, no. 1, 2017.

[24] M. Fadhli, "Manajemen Peningkatan Mutu Pendidikan", TADBIR : Jurnal Studi Manajemen Pendidikan, vol. 1, no 02, 2017.

[25] J. Damanik, "Keterkaitan Standar Pelayanan Minimal (SPM) Dengan Standar Nasional Pendidikan (SNP)". JDP volume 10, no. 2, 2017. 